\title{
Social Support for Seniors Living in the Home Environment ${ }^{1}$ Adéla Mojžíšová and Bohdana Břízová
}

DOI: $10.32725 /$ cetv.2021.021

\begin{abstract}
:
Social support is very important for a happy old age. It affects a person's health and mental well-being and is also perceived as a protective factor of social exclusion in old age. The aim of the article is to present partial results of quantitative research done in the field. In the research, data collection was performed with the use of the PAPI methodology. The research group was seniors aged 65 and older living in their own household. The research is a part of the project 'Sociální vyloučení u seniorů 65+ žijících v domácím prostředí v ČR' (Social exclusion in Seniors Aged 65+ Living in the Home Environment in the Czech Republic). The results of the research did not show that seniors were a socially excluded group. Most seniors living in their own households claimed to have enough social contacts and did not feel lonely. They perceived family, friends, neighbours, the community, and contacts with them as important social support. This was influenced by age and health factors, though. An interesting finding was also the role of the municipality in creating a supportive environment for the quality of life of seniors in the community and natural encounters of individuals during volunteering.
\end{abstract}

\section{Key Words}

Senior, social support, family, social exclusion, community

\section{Introduction}

The aim is to present partial quantitative findings concerning the possibilities of social support as a tool for the prevention of social exclusion of seniors. Social support ${ }^{2}$ appears to be very important for a happy life in old age. According to Šolcová and Kebza, ${ }^{3}$ it is an important factor

1 The paper was supported within the scientific project solution COST LTC 18066 'Social exclusion of seniors living in the home environment in the Czech Republic' subsidised by the Ministry of Education of the Czech Republic in the INTER-EXCELLENCE programme, INTER-COST subprogramme.

2 Fikret GüLACTI, The effect of perceived social support on subjective well-being, Procedia Social and Behavioral Sciences, 2(2)/2010, pp. 3844-3849.

3 Iva ŠOLCOVÁ and Vladimír KEBZA, Sociální opora jako významný protektivní faktor. Československá psychologie. 43(1)/1999, pp. 
influencing a person's health and mental well-being as well as an important preventive tool for the social exclusion of seniors.

According to Cohen, ${ }^{4}$ social support can be understood as social resources that a person perceives as available or that are actually provided to them by non-professionals within formal support groups or informal relationships. For the elderly, social support received from family members ${ }^{5}$ is the most important. According to Vohralíková, ${ }^{6}$ a well-functioning family provides mental and physical as well as material support. The family is often involved in the activity of the individual, thus becoming an important reference framework for the life of the elderly. It is important to draw attention to the individuation in family relationships - a harmonious relationship will certainly have a positive effect on seniors while a cold to hostile relationship can lead to the social exclusion of seniors. In harmonious family relationships, you can observe respect for older members on the one hand, but respect and support for younger members of the family on the other. ${ }^{7}$

As a rule, a senior is a respected member of society ${ }^{8}$ despite the fact that various pitfalls are stemming from the old age. Priby $1^{9}$ explains the term senior as an emotionally neutral concept, acceptable for various scientific disciplines such as sociology, medicine, psychology, etc., and as a term that can be used to describe an individual throughout aging, disregarding their abilities and self-sufficiency.

Aging is perceived as a natural course of life. Langmeier, ${ }^{10}$ similar to Vašutová, ${ }^{11}$ understands old age as a set of changes in the structures and functions of the organism resulting in higher vulnerability and reducing the performance and abilities of the individual, although Haškovcová ${ }^{2}$ points out that each person ages differently - faster in some stages while slower in others. It is a phase of human life determined by two points in time - the upper age limit is sharply defined by death while the lower age limit is blurred by the fact that the phenomena and processes that old age entails enter life gradually and only the aggregate constitutes old age. ${ }^{13}$ Čevela $^{14}$ clearly summarises that old age is an objective reality with manifestations and consequences of physical, functional, and social changes that are very individual and happen at a specific speed and lead to the phenotype of old age which is influenced by the environment, health, lifestyle, and psychological or socioeconomic consequences.

Říčan ${ }^{15}$ states that the World Health Organisation divides later life periods into early old age (higher age, 60-74), old age (advanced age, 75-89), and longevity (90 and over). Foreign authors such as Aldwin ${ }^{16}$ point out that in some cases, old age is defined in the literature as the age of 65 , while in other cases the turning point is 60 years of age, and in some cases it may already be 50 years

19-38.

4 Sheldon COHEN, Social support measurement and intervention: A guide for health and social scientists, New York: Oxford University Press, 2000, p. 53.

5 GüLACTI, The effect..., p. 52.

6 (C) Lenka VOHRALÍKOVÁ, Čeští senioři včera, dnes a zítra, (online), available at http://praha.vupsv.cz/Fulltex t/vz_149.pdf, cited 27th June 2020.

KLEVETOVÁ, Motivační ..., p. 90.

8 Helena HAŠKOVCOVÁ, Fenomén stáří, Praha: Havlíček Brain Team, 2010, p. 12.

9 Hugo PŘIBYL, Lidské potřeby ve stář́, Praha: Maxdorf, 2015, p. 11.

10 Josef LANGMEIER, Vývojová psychologie, Praha: Grada, 2006, p. 185.

11 Maria VAŠUTOVÁ, Základy biodromální psychologie, Ostrava: Ostravská univerzita v Ostravě, p. 265.

12 HAŠKOVCOVÁ, Fenomén ..., p. 172.

13 Petr SAK, Sociologie stárí a seniorỉ, Praha: Grada, 2012, p. 105.

14 Rostislav ČEVELA, Sociální gerontologii: Úvod do problematiky, Praha: Grada, 2012, p. 20.

15 Pavel ŘíČAN, Cesta životem, Praha: Portál, 2006, p. 335.

16 Carolyn, ALDWIN, Health, illness, and optimal aging: Biological and psychosocial perspectives, New York: Springer Publishing Company, 2013, p. 31. 
of age. In the Czech Republic, Haškovcová ${ }^{17}$ moves the range of old age by 5 years compared to WHO and defines early old age (young seniors, 65-74), old age (old seniors, 75-85) and longevity (very old seniors, 85 and over). Some authors ${ }^{18}$ even move the old age limit to 70 and over.

Hegyi $^{19}$ divides age according to various aspects into chronological, biological, functional, psychological, and social age while the individual age may vary. Biological age, also subjective age, can change in response to personal experience that mingles with changes in emotional age, age appearance, and age-appropriate interests. ${ }^{20}$

$\mathrm{Kebza}^{21}$ divides social support into individual and institutional. Individual (or personal) social support is the effort of an individual to help another specific person while institutional (or social) support is understood by the author as assistance implemented or covered under the umbrella of a formal organisation.

Social support is also considered to satisfy the basic social needs of a person through social interactions ${ }^{22}$ - it can be the need for social contact, friendship, attachment, the need for mutuality, communication, social comparison, cooperation, social security, social inclusion, and social identity, or positive social evaluation.

Social support has several aspects referred to as types of social support. Křivohlavý ${ }^{23}$ introduces instrumental support that he perceives as assistance using specific instruments as well as assistance given to those in need. It is tangible and material help or provision of certain things to assist you. The same author describes information support which refers to providing information that will help you solve your situation and become oriented in the problem. It can be the advice of loved ones as well as professional advice. Emotional support is provided and communicated through emotional closeness based on love, empathy, and understanding. Finally, the author mentions evaluation support which helps to strengthen self-esteem and self-confidence and maintains the effort for self-regulation, and encourages faith and hope.

In order to receive the necessary support, you must be integrated into a social network in which social interactions exist and relationships are created that will enable you to receive social assistance. ${ }^{24}$ In old age, therefore, social interactions are very important, but at the same time the elderly need some privacy and should not be overwhelmed by social stimulation. ${ }^{25}$ For this reason, older people prefer to meet people they know well because they know what to expect from them. In older age, more emphasis is placed on depth and length of friendship and less close relationships are reduced over time while satisfaction with deeper relationships increases, says the author. Phillips ${ }^{26}$ mentions that relationship quality rather than quantity has a very positive effect on seniors.

The elderly who receive as well as provide social support are more satisfied than those who only receive or only provide it. The least satisfied are those who do not encounter any form of social

17 HAŠKOVCOVÁ, Fenomén ..., p. 11.

18 Kateřina THOROVÁ, Vývojová psychologie: proměny lidské psychiky od početí po smrt, Praha: Portál, 2015, p. 452.

19 Ladislav HEGYI, Klinické a sociální aspekty ošetrovania starších ludí, Trnava: Slovak Academic Press, 2001, p. 15.

20 Martina GABRIAN, Being slower, feeling older? Experimentally induced cognitive aging experiences have limited impact on subjective age, European Journal subjective age 14(2)/2017, pp. 179-188.

21 Vladimír KEBZA, Psychosociální determinanty zdraví, Praha: Academia, 2005, p. 160.

22 Jaro KŘIVOHLAVÝ, Moderátor zvládání zátěže typu sociální opory, Československá psychologie, 43(2)/1999, pp. 106-118.

23 Jaro KŘIVOHLAVÝ, Psychologie zdraví, Praha: Portál, 2009, p. 279.

24 Zdeněk KRPOUN, Sociální opora: Shrnutí výzkumné činnosti v české a slovenské oblasti a inspirace do budoucnosti - nadané děti, E-psychologie, 6(1)/2012, pp. 42-50.

25 Marie VÁGNEROVÁ, Vývojová psychologie II: Dospělost a stáří, Praha: Karolinu, 2007, p. 411.

26 David PHILLIPS, Informal social support and older persons' psychological well-being in Hong Kong, Journal of Cross-Cultural Gerontology, 23(1)/2008, pp. 39-55. 
support. Thus, not only social support as such is important, but above all the mutuality of support provision. ${ }^{27}$

\section{Methods and Data}

The aim of the paper is to present partial quantitative findings concerning the possibilities of social support in the context of the project 'Social exclusion of seniors 65+ living in the home environment in the Czech Republic'. The main objective of the whole project in which these partial results are published was to identify the forms, causes, and consequences of social exclusion of seniors aged 65 and older living in their own homes. In terms of age for research, seniors are defined as persons over 65 years of age. Seniors living in their own homes are those who have permanent residence in various types of housing - their own house or flat, or rented premises. Therefore, these are the elderly who do not live in social welfare institutions (e.g., elderly homes). The household is considered as a physically demarcated, institutionalised, inhabited, and organised space while, at the same time, as a group of people who live in and manage the household together and carry out a number of joint activities relating to this space. ${ }^{28}$

For our research, a quantitative research strategy was used and the PAPI data collection methodology was applied in the field survey. It is a personal interview with respondents where answers are recorded in a printed questionnaire. The questionnaire included 77 questions divided into 11 chapters on 26 pages. Some of the questions formed batteries. By virtue of the pilot survey, the questions were well understood and focused on the subjective perception of loneliness of seniors, the frequency and various forms of seniors' interactions with family and friends, the activities of seniors within the community, and the level of participation. The survey data consisted of 1,172 questionnaires, and 2 questionnaires were excluded for incompleteness. The research group consisted of seniors aged 65 and older living in their own homes. This was a representative quota sample of respondents. Survey quotas were set for the general population of $65+$ years of age, sorted by age, sex, size of municipality, and region. This classification was based on the available CZSO Demography data 2017.

The quantitative data were processed by the SPSS software (version 21.0), and later by Microsoft Excel (in some cases for descriptive statistics). Descriptive statistics were used to identify the essential characteristics in the research samples. Pearson's chi-square test (at the significance level $a=0.05$ ) was used to test the hypothesis about the dependence of qualitative indicators (Tables 2 and 5). Contiguous categories were combined if the occurrence of some values was too low.

\section{Interpretation of Results}

\section{Loneliness perceived in old age}

For research purposes, it was important to identify the overall average level of loneliness in the research group, and then correlate this average value with selected variables. The survey results show that approximately a third of respondents feel lonely while two thirds do not feel so. For seniors who feel lonely, the level of loneliness is very individual. Loneliness is always a subjective experience. Matoušek ${ }^{29}$ points out that loneliness is not synonymous with objective social isolation.

27 Ik Ki KIM and Cheong-Seok KIM, Patterns of family support and the quality of life of the elderly, Social Indicators Research, 62(1)/2003, pp. 437-454.

28 Zdeněk NEŠPOR, Sociologická encyklopedie, Praha: Sociologický ústav AV ČR, 2017, p. 77.

29 Oldřich MATOUŠEK, Sociální práce v praxi: Specifika různých cílových skupin a práce s nimi, Praha: Portál, 2010, p. 90. 
Table 1: Frequencies of respondent answers to the level of loneliness

\begin{tabular}{|l|l|l|l|}
\hline Q: How do you perceive/measure your loneliness? (Indicate the level of loneliness on the scale.) \\
\hline Scale & Frequency & Percentage & $\begin{array}{l}\text { Percentage of seniors } \\
\text { who feel lonely and } \\
\text { marked the scale }\end{array}$ \\
\hline $\mathbf{1}$ - minimum & 5 & 0.4 & 1.4 \\
\hline $\mathbf{2}$ & 27 & 2.3 & 7.4 \\
\hline $\mathbf{3}$ & 68 & 5.8 & 18.6 \\
\hline $\mathbf{4}$ & 47 & 4 & 12.9 \\
\hline $\mathbf{5}$ & 71 & 6.1 & 19.5 \\
\hline $\mathbf{6}$ & 44 & 3.8 & 12.1 \\
\hline $\mathbf{7}$ & 38 & 3.2 & 10.4 \\
\hline $\mathbf{8}$ & 44 & 3.8 & 12.1 \\
\hline $\mathbf{9}$ & 15 & 1.3 & 4.1 \\
\hline $\mathbf{1 0}$ - maximum & 6 & 0.5 & 1.6 \\
\hline Total & $\mathbf{3 6 5}$ & 31.1 & 100 \\
\hline $\begin{array}{l}\text { Seniors who do not feel lonely and } \\
\text { did not mark the scale }\end{array}$ & 807 & 68.9 & \\
\hline Total & $\mathbf{1 1 7 2}$ & 100 & \\
\hline
\end{tabular}

Source: COST LTC 18066 'Social exclusion of seniors living in the home environment in the Czech Republic' subsidised by the Ministry of Education of the Czech Republic in the INTER-EXCELLENCE programme, INTER-COST subprogramme.

The research clearly indicates the considerable differences in the perception of loneliness based on several socio-demographic indicators. The analysis of (non)dependence (Table 2) shows a statistically significant relationship between loneliness and marital status as well as loneliness and sharing or non-sharing of a household with another person. Living in marriage as well as sharing a household with another person leads to the feeling of loneliness far less often than if respondents are divorced/widowed/single or if respondents live alone; in addition, such respondents often perceive/ measure their loneliness in the second half of a ten-point scale. The same conclusions were reached by Kowaliková and Chyti ${ }^{30}$ who also demonstrated the relationship between a single-member senior household and the level of loneliness. As a contrast, the authors mention Matoušek's ${ }^{31}$ idea that many people can be alone without feeling lonely. Significant dependence was also demonstrated between loneliness and state of health and between loneliness and self-sufficiency assessment. Respondents who mentioned very good or rather good health, or self-sufficiency, suffer far less from loneliness than respondents who reported very poor or rather poor health, or self-sufficiency. The neither good nor bad evaluation of these two indicators did not bear on the perception of loneliness. On the contrary, the weakest relationship was identified between loneliness and age $(p=0.825)$. Given the p-value, the feeling of loneliness seems to be independent of age.

30 Ivana KOWALIKOVÁ and Oldřich CHYTIL, Souvislost mezi anticipovanou dostupností sociální opory a kvalitou života seniorů: implikace pro sociální práci. Sociální práce/Sociálna práca. 19(3)/2019, pp. 62-81.

31 MATOUŠEK, Sociální ...., p. 90. 
The research also showed a significant difference in the perception of loneliness between men and women $(\mathrm{p}=0.001)$. The reason may be women's greater emotional dispositions, but rather more important is the fact there are more women than men in higher age groups as well as among people without marriage or without other members of the household.

Table 2: Correlation analysis between loneliness and selected socio-demographic indicators

\begin{tabular}{|c|c|}
\hline \multicolumn{2}{|l|}{ Do you personally feel lonely? } \\
\hline & p-value \\
\hline Age & 0.825 \\
\hline Marital status & $\ll 0.0001$ \\
\hline Sharing the household with another person & $\ll 0.0001$ \\
\hline State of health & $\ll 0.0001$ \\
\hline Self-sufficiency assessment & $\ll 0.0001$ \\
\hline
\end{tabular}

Source: COST LTC 18066 'Social exclusion of seniors living in the home environment in the Czech Republic' subsidised by the Ministry of Education of the Czech Republic in the INTER-EXCELLENCE programme, INTER-COST subprogramme.

\section{Family and friends as social support}

One of the important tools for the prevention of loneliness is the family of an elder and their social interactions (Table 3). The research showed that less than half of the senior respondents have daily interaction with their family whether in person or by telephone. Most of the others have weekly interaction with their family, and a low percentage of respondents have only several interactions per year, or none at all.

Table 3: Social interaction between the elderly and their family (close relatives) and friends

\begin{tabular}{|l|l|l|l|l|}
\hline \multicolumn{5}{|l}{ Frequency of interaction with family and friends } \\
\hline & $\begin{array}{l}\text { Family - Personal } \\
\text { Contact }\end{array}$ & $\begin{array}{l}\text { Family - Telepho- } \\
\text { ne Contact }\end{array}$ & $\begin{array}{l}\text { Friends - Personal } \\
\text { Contact }\end{array}$ & $\begin{array}{l}\text { Friends - Telephone } \\
\text { Contact }\end{array}$ \\
\hline Daily & $538(45.6 \%)$ & $479(40.9 \%)$ & $197(16.8 \%)$ & $168(14.3 \%)$ \\
\hline Weekly & $380(32.4 \%)$ & $437(37.3 \%)$ & $463(39.5)$ & $472(40.3 \%)$ \\
\hline Bi-weekly & $95(8.1 \%)$ & $79(6.7 \%)$ & $180(15.4 \%)$ & $206(17.6 \%)$ \\
\hline Monthly & $74(6.3 \%)$ & $37(3.2 \%)$ & $169(14.4 \%)$ & $123(10.5 \%)$ \\
\hline $\mathbf{1 - 5}$ per year & $27(2.3 \%)$ & $14(1.2 \%)$ & $54(4.6 \%)$ & $34(2.9 \%)$ \\
\hline $\begin{array}{l}\text { Less } \\
\text { frequently }\end{array}$ & $14(1.2 \%)$ & $19(1.6 \%)$ & $47(4.0 \%)$ & $50(4.3 \%)$ \\
\hline $\begin{array}{l}\text { No interac- } \\
\text { tion at all }\end{array}$ & $19(1.6 \%)$ & $37(3.2 \%)$ & $28(2.4)$ & $61(5.2 \%)$ \\
\hline $\begin{array}{l}\text { Did not } \\
\text { respond }\end{array}$ & $25(2.1 \%)$ & $70(6.0 \%)$ & $34(2.9)$ & $58(4.9 \%)$ \\
\hline Total & $1172(100 \%)$ & $1172(100 \%)$ & $1172(100 \%)$ & $1172(100 \%)$ \\
\hline
\end{tabular}


Source: COST LTC 18066 'Social exclusion of seniors living in the home environment in the Czech Republic' subsidised by the Ministry of Education of the Czech Republic in the INTER-EXCELLENCE programme, INTER-COST subprogramme.

However, our research outcomes are in accordance with Phillips's ${ }^{32}$ opinion that the quality of family relationship is more important than the quantity. Seniors claim that personal contact unlike telephone contact is influenced by residence and logically by the number of household members. Both types of interactions show a slight interdependence on the state of health where people suffering from poor health do not socially interact with their family as frequently as healthy people. We consider it alarming because, according to Petrová Kafková, ${ }^{33}$ the poor health of an elderly person implies dependence on assistance and the support of others, especially families. After all, our research also makes it obvious that the closest person to an elderly person is their spouse / husband or wife if they have one. Older respondents without a spouse cling to their children where the daughter is mentioned almost twice as often as the son. Tabakováa ${ }^{34}$ and Tošnerová ${ }^{35}$ also state that responsibility for the care of an elderly person is most often assumed by one family member, mainly a daughter. In the Czech environment, these are often (in three quarters of cases) the primary caregivers.

The interaction of seniors with family members is proved to be more frequent than interaction with friends as they grow older and lose their self-sufficiency. The interaction between a senior and the family is most common on a weekly basis, either personal or by telephone ( $41 \%$ and $42 \%$ respectively). About $16 \%$ of respondents report daily interaction with their friends whether in person or by telephone. Also, having social interaction several times per month is not unusual. Interaction with friends already shows a slight dependence on the respondent's age. Haškovcová ${ }^{36}$ states that especially able-bodied seniors may not feel comfortable about interaction with their peers who are not as physically and mentally fit as they are because they are, in fact, looking at a possible future of their own, with which they are usually not internally reconciled. Another important factor mentioned by Haškovcová ${ }^{37}$ is so-called collective memory, a technical term for shared experiences of one generation: the social and historical events that other generations have not experienced.

The research also identified the nature of mutual assistance and social support that is most frequent among close relatives, followed by friends and neighbours. The proportion of seniors providing assistance and support decreases with age, related both to family and friends and neighbours. For the elderly, receiving assistance slightly prevails over providing it in all three cases (Table 4).

32 PHILLIPS, Informal ..., p. 105

33 Marcela PETROVÁ KAFKOVÁ, Mezigenerační solidarita ve stárnoucí společnosti, Sociální studia/Social Studies, 7(4)/2015, pp. 63-84.

34 Mária TABAKOVÁ, Caregiver role strain - content validation of nursing diagnosis in Slovakia and the Czech Republic, Profese, $4(2) / 2011$, pp. $27-32$.

35 Tamara TOŠNEROVÁ, Pocity a potřeby pečujících o starší rodinné př́slušníky, Praha: Ústav lékařské etiky 3. LF UK Praha, p. 32.

36 HAŠKOVCOVÁ, Fenomén ..., p. 53.

37 Ibid., p. 140. 
Table 4: Mutual assistance

\begin{tabular}{|l|l|l|l|l|}
\hline \multicolumn{2}{|l}{ Mutual assistance between seniors and their closest environment } & \multicolumn{1}{l|}{$\begin{array}{l}\text { Did not re- } \\
\text { spond }\end{array}$} & Total \\
\hline & Yes & No & $3(0.3 \%)$ & $1172(100 \%)$ \\
\hline $\begin{array}{l}\text { Do you help your closest } \\
\text { relatives? }\end{array}$ & $840(71.7 \%)$ & $329(28.1 \%)$ & $1172(100 \%)$ \\
\hline $\begin{array}{l}\text { Do your closest relatives help } \\
\text { you? }\end{array}$ & $971(82.8 \%)$ & $193(16.5 \%)$ & $8(0.7 \%)$ & $1172(100 \%)$ \\
\hline $\begin{array}{l}\text { Do you help your closest } \\
\text { friends? }\end{array}$ & $721(61.5 \%)$ & $445(38.0 \%)$ & $6(0.5 \%)$ & $1172(100 \%)$ \\
\hline $\begin{array}{l}\text { Do your closest friends help } \\
\text { you? }\end{array}$ & $768(65.5 \%)$ & $397(33.9 \%)$ & $7(0.6 \%)$ & $1172(100 \%)$ \\
\hline $\begin{array}{l}\text { Do you help your neighbours? } \\
\text { Do your neighbours help you? }\end{array}$ & $537(45.8 \%)$ & $645(55.0 \%)$ & $9(0.8 \%)$ & $1172(100 \%)$ \\
\hline
\end{tabular}

Source: COST LTC 18066 'Social exclusion of seniors living in the home environment in the Czech Republic' subsidised by the Ministry of Education of the Czech Republic in the INTER-EXCELLENCE programme, INTER-COST subprogramme.

Baštecká ${ }^{38}$ mentions reciprocal social support where the senior not only receives but also gives help to others. It was found that $83 \%$ of respondents receive assistance from their close relatives, $66 \%$ from friends, and $46 \%$ from neighbours. On the contrary, $72 \%$ of the senior research sample provide assistance for their close relatives, $62 \%$ to friends and $45 \%$ to neighbours. Assistance for seniors increases with their age only in the case of support from close relatives. The receipt of assistance does not depend on whether the senior in question lives with someone or not. It is interesting that close relatives more often help women than men and friends more often help men than women (Hamplováa ${ }^{39}$.

\section{Community life as social support}

$\mathrm{Wija}^{40}$ states that municipalities play an important role in creating the conditions for a high quality and active life of their population as well as in creating a supportive environment that allows older people to stay in their own natural environment and housing and fully participate in the life of the 'community' and in the development of intergenerational relationships ('age-friendly cities' according to WHO). However, our research showed (Table 5) that there is no voluntary activity within the community that involves more than $40 \%$ of seniors. The elderly most often help each other (37\%) and mutual assistance between seniors is more often seen in the community of municipalities with a population of less than 4,999 . Only $27 \%$ of seniors in the research sample stated that they provide assistance for a younger generation, and it more often concerns younger

38 Bohumila BAŠTECKÁ, Psychosociální krizová spolupráce, Praha: Grada Publishing, 2013, p. 75.

39 Dana HAMPLOVÁ, Rodina a zdraví - jejich vzájemné souvislosti, Praha: SLON, 2014, p. 103.

40 Petr WIJA, Město pro všechny generace: Role samospráv v podpoře aktivního stárnutí v komunitě, (online), available at: https://clanky. rvp.cz/clanek/c/Z/20629/MESTO-PRO-VSECHNY-GENERACE-ROLE-SAMOSP RAV-V-PODPORE-AKTIVNIHO-STARNUTI-VKOMUNITE.html/, cited $27^{\text {th }}$ June 2020. 
respondents, namely seniors under 70, with at least a high school diploma. In the community, $19 \%$ of the interviewed seniors participate in natural history activities looking into the history of the surroundings where they live, and also most often in smaller places with a population of less than 4,999. Those who teach their skills are $14 \%$, being more often men and respondents with a university degree. Also, 12\% participate in house, neighbourhood or senior councils and commissions, which is more the case for residents of cooperative housing and larger cities with populations of 20-99 thousand.

Table 5: Voluntary activities of seniors

\begin{tabular}{|l|l|l|l|l|}
\hline \multicolumn{2}{|l|}{ Participation of seniors in voluntary activities in the community } \\
\hline & Yes & No & $\begin{array}{l}\text { Did not } \\
\text { respond }\end{array}$ & Total \\
\hline Assistance for younger generation & $314(26.8 \%)$ & $847(72.3 \%)$ & $11(0.9 \%)$ & $1172(100 \%)$ \\
\hline Assistance for other seniors & $430(36.7 \%)$ & $732(62.5 \%)$ & $10(0.9 \%)$ & $1172(100 \%)$ \\
\hline Teaching skills acquired during life & $160(13.7 \%)$ & $1000(85.3 \%)$ & $12(1.0 \%)$ & $1172(100 \%)$ \\
\hline Talking history of the area & $214(18.3 \%)$ & $942(80.4 \%)$ & $16(1.4 \%)$ & $1172(100 \%)$ \\
\hline $\begin{array}{l}\text { Participation in house councils and } \\
\text { commissions }\end{array}$ & $142(12.1 \%)$ & $1018(86.9 \%)$ & $12(1.0 \%)$ & $1172(100 \%)$ \\
\hline Participation in election commissions & $108(9.2 \%)$ & $1052(89.8 \%)$ & $12(1.0 \%)$ & $1172(100 \%)$ \\
\hline Participation in parish activities & $71(6.1 \%)$ & $1094(93.3 \%)$ & $7(0.6 \%)$ & $1172(100 \%)$ \\
\hline $\begin{array}{l}\text { Participation in at least one voluntary } \\
\text { activity }\end{array}$ & $1118(95.4 \%)$ & $54(4.6 \%)$ & $0(0 \%)$ & $1172(100 \%)$ \\
\hline
\end{tabular}

Source: COST LTC 18066 'Social exclusion of seniors living in the home environment in the Czech Republic' subsidised by the Ministry of Education of the Czech Republic in the INTER-EXCELLENCE programme, INTER-COST subprogramme.

In terms of voluntary activities in the communities, the senior respondents mentioned assistance in organising social events, taking care of public space, engagement in fire brigades, membership in various interest groups, or political involvement. The authors conclude that community activities of seniors in the research sample are associated with age, health, and education of the elderly and take place more often in small municipalities with a population of less than 4,999 where they influence the quality of life and cohesion of the population.

Table 6 shows the data analysis of the relationship between the size of municipality and the involvement of seniors in selected voluntary activities. The involvement in assistance for the younger generation and other seniors, in teaching skills and talking history is higher in municipalities with a population less than 999, however, only at the level of significance $\alpha=0.10$. At the same time, helping other seniors and talking history is lower in cities with a population more than 100,000 which contributes to a statistically significant dependence between the size of municipality and these two activities ( $\mathrm{p}=0.0093$ and $\mathrm{p}=0.033$ respectively). As expected, the participation in house councils is statistically far less frequent in municipalities with less than 999 inhabitants 
and above average in cities with population of 20,000 to 99,999 which leads to high statistical significance $(p=0.0052)$. Participation in election commissions is generally low and does not depend on the size of municipality. A small number of seniors are involved in parish activities (6.1\% of respondents), but this involvement is statistically significant depending on the size of the municipality ( $\mathrm{p}=0.0098$ ) with an above-average participation in municipalities with less than 999 inhabitants and a significantly low participation in cities with population of 20,000 to 99,999 .

Table 6: Relationship between voluntary activities and the municipality size

\begin{tabular}{|l|l|}
\hline \multicolumn{2}{|l|}{ Relationship between voluntary activities and the municipality size } \\
\hline & $p$-value \\
\hline Assistance for younger generation & 0.079 \\
\hline Assistance for other seniors & 0.0093 \\
\hline Teaching skills acquired during life & 0.083 \\
\hline Talking history of the area & 0.0331 \\
\hline $\begin{array}{l}\text { Participation in house councils and commissi- } \\
\text { ons }\end{array}$ & 0.0052 \\
\hline Participation in election commissions & 0.778 \\
\hline Participation in parish activities & 0.0098 \\
\hline
\end{tabular}

Source: COST LTC 18066 'Social exclusion of seniors living in the home environment in the Czech Republic' subsidised by the Ministry of Education of the Czech Republic in the INTER-EXCELLENCE programme, INTER-COST subprogramme.

Overall, more than half of the respondents are involved in community activities which the authors perceive as very positive since maintaining these activities is key to ensuring higher levels of life satisfaction in old age.

Our findings considering the risk of social exclusion should lead to an active search for those seniors who are lonely. It is obvious that their links to informal support and assistance systems - especially family, friends, extended family, or neighbours, or possibly to formal support and assistance systems (seniors' clubs) ${ }^{41}$ - should be reinforced through social work. In this respect, municipalities (municipal management) could play a key role and they should be aware of this fact and actively approach their seniors. Other institutions that could be involved are social service organisations - for example, the revision of the care service and its focus on prevention seems to be key in this regard. The lack of capacity to solve this problem is discussed by Kowaliková and Chytil ${ }^{42}$ who state that there are no social services in the Czech Republic that would primarily provide affordable social support to the elderly in difficult life situations who live in a single-person household. At the individual level, we recommend people in the middle age and the 50+ generation to develop, support, and foster above all their social connections so that their

41 KOWALIKOVÁ, CHYTIL, Souvislost..., p. 77.

42 Ibid. 
relationships with friends last until the senium and can be a source of social support. We perceive a stable network of friendly relations as a protective factor against social exclusion in old age. However, social support not only concerns the support of seniors in the family, but also the involvement of seniors in the community, typically in municipalities with a population of less than 4,999. Therefore, those municipalities can be considered as a suitable space for creating a supportive environment for the quality of life of senior citizens in the community. In this respect, the support of senior or intergenerational contact centres, and events intended (not only) for seniors, or leisure and educational activities suitable for seniors are recommended because joint work and dialogue lead to understanding, friendship, and mutual respect. The natural form of contact can also be realised in volunteer activities.

\section{Conclusion}

The paper presents partial results of the project aimed at identifying the forms, causes, and consequences of social exclusion in seniors aged 65 and older who live in the home environment. Given that it was a representative research sample, the research results can be generalised to the entire senior population in the Czech Republic who live in their own homes. The main topic of the paper was the social support of seniors living in their own homes. The outcomes show that interactions with family, friends, and neighbours, and the community provide important social support for seniors, but they are influenced by factors such as self-sufficiency, state of health, and the type of household of a senior. Social work with the elderly should therefore intervene appropriately and support the senior's safety, family interactions, and informal carers, or volunteering activities. ${ }^{43}$

\section{Contact}

\section{Assoc. Prof. Dr Adéla Mojžíšová}

University of South Bohemia in České Budějovice

Faculty of Health and Social Sciences

Institute of Social and Special-Paedagogical Sciences

J. Boreckého 1167/27, 37011 České Budějovice

mojzis@zsf.jcu.cz

\section{Dr Bohdana Břizová}

University of South Bohemia in České Budějovice

Faculty of Health and Social Sciences

Institute of Social and Special-Paedagogical Sciences

J. Boreckého 1167/27, 37011 České Budějovice

brizova@zsf.jcu.cz

43 The authors thank Assoc. Prof. Vladimir Rogalewicz, CSc. and PhDr. Miroslav Barták for consulting statistical processing and data interpretation. 